\title{
Upaya Mencegah Pelanggaran Praktik Monopoli Yang Dilakukan Oleh PT. Angkasa Pura
}

\author{
Ovilia Shely Fadhila \\ Magister Ilmu Hukum Fakultas Hukum Universitas Islam Indonesia \\ Jln. Cik Di Tiro No. 1 Yogyakarta \\ ovilia.shely@gmail.com
}

\begin{abstract}
This study discusses two legal questions: first, why the airport administration carried out by PT Angkasa Pura (Persero) violates Article 50 letter a and Article 51 of Law No. 5 of 1999 on the Prohibition of Monopoly and Unfair Business Competition? Second, how are the arrangements for the implementation of airport business activities in accordance with the competition law? The research method used is normative juridical. The results of the study conclude, first, the airport administration carried out by PT Angkasa Pura I (Persero) and PT Angkasa Pura II (Persero) as BUMN based on the 3 Decisions of the Business Competition Supervisory Commission (KPPU) violates the prohibition of monopolistic practices due to inconsistency in the behavior of business actors in carrying out business activity contract that they carry out monopolistic practices beyond the rules stipulated in the provisions of the laws and regulations. Second, the government can refer to the OECD Regulatory Impact Assessment Toolkit, which is a systemic approach to critically assess the positive and negative effects of regulation and non-regulatory alternatives related to airport administration. In addition, it is also very necessary to improve the regulations for airport business governance which are still centralistic and monopolistic in nuances.
\end{abstract}

Key Words: Airport; monopoly; PT Angkasa Pura (Persero)

\begin{abstract}
Abstrak
Penelitian ini membahas dua pertanyaan hukum: pertama, mengapa penyelenggaraan kebandarudaraan yang dilakukan oleh PT Angkasa Pura (Persero) melanggar Pasal 50 huruf a dan Pasal 51 Undang-Undang No. 5 Tahun 1999 tentang Larangan Monopoli dan Persaingan Usaha Tidak Sehat? Kedua, bagaimana pengaturan penyelenggaraan kegiatan usaha kebandarudaraan yang sesuai dengan hukum persaingan usaha? Metode penelitian yang digunakan adalah yuridis normatif. Hasil penelitian menyimpulkan, pertama, penyelenggaraan kebandarudaraan yang dilakukan oleh PT Angkasa Pura I (Persero) dan PT Angkasa Pura II (Persero) selaku BUMN berdasarkan dari 3 Putusan Komisi Pengawas Persaingan Usaha melanggar larangan praktik monopoli karena inkonsistensi perilaku pelaku usaha dalam menjalankan kontrak kegiatan usaha kebandarudaraan sehingga melakukan praktik monopoli di luar kaidah yang ditentukan dalam ketentuan peraturan perundang-undangan. Kedua, pemerintah dapat mengacu OECD Toolkit Regulatory Impact Assessment yaitu pendekatan sistemik untuk menilai secara kritis efek positif dan negatif dari regulasi dan alternatif non-regulasi yang berkaitan dengan penyelenggaraan kebandarudaraan. Selain itu juga sangat diperlukan perbaikan regulasi tata kelola usaha kebandarudaraan yang masih bernuansa sentralistik dan monopolistik.
\end{abstract}

Kata-kata Kunci: Monopoli, bandar udara, PT Angkasa Pura (Persero). 


\section{Pendahuluan}

Transportasi merupakan sarana penting untuk menunjang akses yang mudah bagi setiap orang yang ingin bepergian. Transportasi dibagi kedalam tiga golongan yaitu transportasi darat, transportasi laut dan transportasi udara. Kepraktisan dan keefisiensian waktu saat ini lebih dicari oleh pengguna jasa penyedia transportasi. Ada berbagai macam usaha dalam dunia penerbangan, seperti: penerbangan domestik; penerbangan internasional; serta penerbangan cargo. ${ }^{1}$

Pasal 232 Undang-Undang No. 1 Tahun 2009 tentang Penerbangan merupakan dasar untuk mengetahui penggunaan jasa fasilitas kebandarudaraan dengan pelayanan jasa terkait bandar udara, perlu mempelajari lebih lanjut. Pentingnya bandar udara sebagai fasilitas penerbangan dalam arti hukum dapat diketahui pertama-pertama dari Annex h, Pasal 1 Konvensi Paris, yang mengharuskan pesawat udara asing untuk take off dan landing di lapangan terbang (airfield) yang ditetapkan khusus untuk itu oleh pejabat yang berwenang. Hampir seluruh negara telah menerima ketentuan itu dalam peraturan perundang-undangannya. ${ }^{2}$

Pengaturan mengenai manajemen pengoperasionalan bandar udara di Indonesia diberikan kepada sebuah perusahaan bernama Angkasa Pura yang terbagi menjadi Angkasa Pura I dan Angkasa Pura II. Ditinjau dari sisi pengelolaan, Bandar Udara di Indonesia pada prinsipnya diselenggarakan oleh pemerintah, yang pelaksanaannya dapat dilimpahkan ke Badan Usaha Milik Negara (BUMN). Pengelolaan bandar udara di Indonesia saat ini sebagian besar diselenggarakan oleh Unit Pelaksana Teknis, baik daerah maupun di bawah Direktorat Jenderal Perhubungan Udara dan sebagian lainnya diselenggarakan oleh PT Angkasa Pura I dan PT Angkasa Pura II. ${ }^{3}$

Angkasa Pura merupakan salah satu Badan Usaha Milik Negara (BUMN) yang bergerak dalam bidang usaha pelayanan jasa kebandarudaraan dan pelayanan jasa terkait bandar udara. PT Angkasa Pura (Persero) sebagai pelaku usaha yang menggusahakan bandar udara, atau yang lebih sering disebut dengan Badan Usaha Bandar Udara (BUBU). ${ }^{4}$ PT Angkasa Pura (persero) dapat dikatakan

\footnotetext{
${ }^{1}$ https://bandara.id/kargo/seputar-kargo-bandara diakses pada jumat, 01 Maret 2019 pukul 11:10 WIB

2 Saefullah Wiradipradja, Pengantar Hukum Udara dan Ruang Angkasa, Buku I Hukum Udara, Bandung: PT Alumni, 2014, hlm. 186

3 Wardani Sartono, et.al., Bandar Udara Pengenalan dan Perancangan Geometrik Runway, Taxiway dan Apron, Yogyakarta, Gadjah Mada University Press, 2016, hlm. 14

${ }_{4}^{4}$ Pasal 1 angka 43 Undang-Undang No. 1 Tahun 2009 tentang Penerbangan.
} 
sebagai badan hukum yang memenuhi persyaratan sebagai Badan Usaha Bandar Udara di Indonesia.

Angkasa Pura selaku BUMN selalu melaksanakan kewajiban untuk membayar deviden kepada negara selaku pemegang saham. Selain itu juga senantiasa berkomitmen untuk memberikan pelayanan yang terbaik dan perlindungan konsumen kepada pengguna jasa bandara, menerapkan praktik tata kelola perusahaan yang baik, meningkatkan kesejahteraan karyawan dan keluarganya serta meningkatkan kepedulian sosial terhadap masyarakat umum dan lingkungan sekitar bandara melalui program Corporate Social Responsibility. ${ }^{5}$

Ada banyak bidang jasa maupun barang yang dapat dikomersialkan dengan beberapa pihak dari segi penanganan fasilitas baik dari sisi Air Side atau Aeronautical service maupun Land Side atau Non-Aeronautical Service. Namun hanya beberapa pihak atau badan usaha saja yang dapat menjadi pengelola suatu bandar udara dalam hal ini hanya Angkasa Pura I dan Angkasa Pura II yang ditunjuk sebagai satu-satunya BUMN yang mengelola jasa kebandarudaraan. Dari hal tersebut peraturan perundang-undangan sebenarnya telah memonopoli pengusahaan jasa kebandarudaraan.

Di beberapa negara, undang-undang anti monopoli seringkali mengesampingkan beberapa tindakan hukum yang tidak dapat dikenakan sanksi atau tindakan itu tidak dianggap sebagai suatu pelanggaran. ${ }^{6}$ Undang-Undang No. 5 Tahun 1999 tentang Larangan Praktek Monopoli dan Persaingan Usaha Tidak Sehat telah menentukan di dalam Pasal 50 dan 51 Bab IX mengenai Ketentuan Lain. Namun sangat disayangkan adanya pasal pengecualian ini tidak dijelaskan lebih lanjut dan hanya disebutkan dengan kalimat "cukup jelas" dalam penjelasan Undang-Undang No. 5 Tahun 1999 sehingga dapat mengakibatkan beragam penafsiran oleh para pelaku usaha.

Penulis dalam konteks ini akan lebih mengkaji mengenai monopoli yang diperbolehkan dalam Pasal 50 huruf a dan Pasal 51 Undang-Undang No. 5 Tahun 1999 karena lebih sesuai dengan topik bahasan yang penulis ajukan. Pasal 50 huruf a Undang-Undang No. 5 Tahun 1999 menentukan bahwa:

"yang dikecualikan dari ketentuan perundang-undangan ini adalah perbuatan dan atau perjanjian yang bertujuan melaksanakan peraturan perundang undangan yang berlaku."

${ }^{5}$ https://www.angkasapura2.co.id/id/tentang/sejarah, diakses pada tanggal 22 Maret 2019 Pukul 12:37

${ }^{6}$ Hikmahanto Juwana, Bunga Rampai Hukum Ekonomi dan Hukum Internasional, Tanpa Kota: Penerbit Lentera Hati, 2001, hlm. 28. 
Pengelolaan beberapa bandar udara di Indonesia sebagaimana yang telah dijelaskan sebelumnya diserahkan kepada PT Angkasa Pura yang terbagi dalam Angkasa Pura I dan Angkasa Pura II yang menaungi wilayahnya masing-masing. Pengelolaan bandar udara diselenggarakan oleh pemerintah yang pelaksanaannya dapat dilimpahkan kepada BUMN. Perlu dipahami bahwa pengecualian yang diatur dalam ketentuan Pasal 50 huruf a Undang-Undang No. 5 Tahun 1999 hanya berlaku bagi pelaku usaha yang dibentuk atau ditunjuk oleh pemerintah. Mengingat secara tegas dikatakan "untuk melaksanakan peraturan perundang-undangan yang berlaku" maka perbuatan pelaku usaha jelas karena adanya "kewenangan" yang diberikan oleh perundang-undangan.7 Selanjutnya mengenai Pasal 51 Undang-Undang No. 5 Tahun 1999 menyebutkan bahwa:

"monopoli dan/atau pemusatan kegiatan yang berkaitan dengan produksi dan/atau pemasaran barang dan/atau jasa yang menguasai hajat hidup orang banyak, serta cabang-cabang produksi yang penting bagi Negara diatur dengan undang-undang dan diselenggarakan oleh Badan Usaha Milik Negara dan atau badan atau lembaga yang dibentuk atau ditunjuk oleh pemerintah".

Pada prinsipnya ketentuan pasal tersebut mengesahkan monopoli yang diatur oleh undang-undang dan diselenggarakan oleh BUMN dan/atau badan atau lembaga yang dibentuk atau ditunjuk oleh pemerintah untuk menyelenggarakan monopoli atas barang dan/atau jasa yang menguasai hajat hidup orang banyak, serta cabang produksi yang penting bagi negara.

Meski telah ada pengecualian dalam Undang-Undang No. 5 Tahun 1999 tentang Larangan Praktek Monopoli dan Persaingan Tidak Sehat yang tertuang dalam Pasal 50 huruf a dan Pasal 51, namun tetap saja pihak Angkasa Pura I dan Angkasa Pura II selaku BUMN yang ditunjuk oleh pemerintah tidak terlepas dari jerat putusan Komisi Pengawasan Persaingan Usaha, sebagaimana dibuktikan dengan adanya beberapa putusan berikut:

1. Putusan No. 13/KPPU-I/2014 tentang Dugaan Pelanggaran terhadap UU No. 5 Tahun 1999 terkait dengan penyedia/ pelayanan jasa Ground Handling terkait penerbangan komersial tidak berjadwal (Irregular Flight) di Bandar Udara I Gusti Ngurai Rai-Bali;

2. Putusan No. 08/KPPU-L/2016 tentang dugaan pelanggaran Pasal 17 ayat (1) dan (2) UU No. 5 Tahun 1999 berkaitan dengan praktik monopoli yang dilakukan oleh PT Angkasa Pura Logistik di terminal kargo Bandar Udara Internasional Sultan Hassanudin Makasar;

${ }^{7}$ Hikmahanto Juwana, Bunga Rampai..., Op. Cit., hlm. 119. 
3. Putusan No. 03/KPPU-I/2017 Tentang dugaan pelanggaran terkait praktik monopoli oleh PT Angkasa Pura II (Persero) dalam Pengiriman (Outgoing) dan Pengambilan (Incoming) kargo dan pos di Bandara Kualanamu.

Berdasarkan putusan-putusan di atas dapat diketahui bahwa kasus monopoli dan persaingan usaha tidak sehat dapat menjerat BUMN yang ditunjuk pemerintah sebagai satu-satunya pengelola tunggal untuk melaksanakan peraturan perundang-undangan. BUMN nampak memanfaatkan kekuasaannya untuk lebih menguasai pasar.

Berkaitan dengan hal yang telah dibahas di atas, artikel ini akan mengkaji permasalahan di bidang jasa kebandarudaraan yang telah diputus oleh Komisi Pengawasan Persaingan Usaha (KPPU). Melalui putusan tersebut penulis hendak menganalisis kembali penyebab dan sisi-sisi kelemahan yang menyebabkan praktik monopoli dari proses penyedia dan pelayanan jasa bandara di Indonesia yang secara operasional dikelola oleh PT Angkasa Pura I dan PT Angkasa Pura II atas perintah dari peraturan perundang-undangan.

Permasalahan di bidang kebandarudaraan menarik dikaji karena semakin tinggi dan berkembangnya usaha-usaha mengenai pelayanan jasa angkutan udara yang semakin diminati oleh masyarakat. Meningkatnya pertumbuhan bisnis dan ekonomi sekitar bandar udara serta pengembangan potensi pariwisata Indonesia yang didukung oleh adanya bandar udara ditempat yang tinggi peminat wisatawannya turut menambah urgensi kajian ini. Oleh karenanya diharapkan adanya persaingan usaha yang sehat dalam pengelolaan bandar udara di indonesia agar tercipta rasa adil serta meningkatkan inovasi usaha antar sesama pelaku usaha dalam sektor jasa kebandarudaraan.

\section{Rumusan Masalah}

Berdasarkan uraian di atas, maka penulis ingin menganalisis mengenai: pertama, mengapa penyelenggaraan usaha kebandarudaraan yang dilakukan oleh PT Angkasa Pura melanggar Pasal 50 huruf a dan Pasal 51 Undang-Undang No. 5 Tahun 1999 tentang Larangan Praktek Monopoli dan Persaingan Usaha Tidak Sehat? Kedua, bagaimana pengaturan penyelenggaraan usaha kebandarudaraan yang sesuai dengan hukum persaingan usaha?

\section{Tujuan Penelitian}

Penelitian ini bertujuan untuk menganalisis penyebab pelanggaran ketentuan praktik monopoli yang dilakukan oleh PT Angkasa Pura berdasarkan Pasal 50 huruf a dan Pasal 51 Undang-Undang No. 5 Tahun 1999 tentang 
Larangan Praktek Monopoli dan Persaingan Usaha Tidak Sehat dan untuk merekomendasikan usulan perbaikan pengaturan penyelenggaraan kegiatan usaha kebandarudaraan yang sesuai dengan hukum persaingan usaha.

\section{Metode Penelitian}

Jenis penelitian ini adalah yuridis normatif yaitu penelitian yang dilakukan terhadap norma hukum tertulis seperti peraturan perundang-undangan, yurisprudensi, traktat, kebiasaan dan lain-lain. Metode penelitian yang digunakan dalam penelitian ini, yaitu penelitian eksplanatoris. Penelitian eksplanatoris adalah penelitian yang dilakukan berdasarkan data-data yang telah ada untuk menganalisa dan menjelaskan kembali suatu permasalahan secara lebih mendalam. ${ }^{8}$

Objek penelitian dalam penelitian ini lebih difokuskan pada produk-produk hukum dimulai dari peraturan perundang-undangan, yurisprudensi, serta Putusan Komisi Pengawas Persaingan Usaha yang berkaitan dengan praktik monopoli PT. Angkasa Pura I dan II. Sedangkan bahan hukum yang digunakan ialah; bahan hukum primer yaitu bahan hukum yang diperoleh dari peraturan perundangundangan dan yurisprudensi yang berlaku dan berkaitan dengan Monopoli dan Persaingan Usaha Tidak Sehat. Bahan hukum sekunder yaitu bahan hukum yang diperoleh secara tidak langsung melalui buku-buku, jurnal, majalah, koran, yang berkaitan dengan permasalahan yang penulis teliti.

\section{Hasil Penelitian dan Pembahasan}

\section{Analisis Pertimbangan Komisi Pengawas Persaingan Usaha terkait Pelanggaran Praktik Monopoli yang dilakukan oleh PT Angkasa Pura}

Putusan KPPU terhadap PT Angkasa Pura I dan PT Angkasa Pura II dalam pengelolaan jasa kebandarudaraan yang menjadi objek analisis peneliti. Tiga putusan itu antara lain Putusan No. 13/KPPU-I/2014 tentang Penyediaan/Pelayanan Jasa Ground Handling Terkait Dengan Penerbangan Komersial Tidak Berjadwal (Irreguler Flight) di Bandar Udara I Gusti Ngurah Rai Bali, Putusan No. 08/KPPU-L/2016 berkaitan dengan Praktek Monopoli yang dilakukan oleh PT Angkasa Pura Logistik di Terminal Kargo Bandar Udara Internasional Sultan Hasanuddin Makassar, dan Putusan Nomor 03/KPPUI/2017 tentang dugaan pelanggaran terkait praktek monopoli oleh PT Angkasa Pura II (persero) dalam pengiriman (outgoing) dan pengambilan (Incoming) kargo dan pos di Bandar Udara Kualanamu Medan.

\footnotetext{
8 Soerjono Soekanto, Pengantar Penelitian Hukum, cet. ketiga, Universitas Indonesia, Jakarta, 1986, hlm. 10.
} 
Fokus utama yang dianalisis dalam ketiga putusan KPPU itu ialah bentukbentuk pelanggaran terhadap Undang-Undang No. 5 Tahun 1999 yang dilakukan oleh PT Angkasa Pura I dan PT Angkasa Pura II sebagai pengelola tunggal yang diberikan kewenangan atas penyelenggaraan jasa kebandarudaraan di Indonesia. Berdasarkan bentuk-bentuk pelanggaran yang ditemukan dalam putusanputusan itu, akan ditarik suatu kesimpulan mengenai hubungan hukum yang menyebabkan terjadinya suatu pelanggaran. Apakah hal tersebut karena perilaku PT Angkasa Pura I dan PT Angkasa Pura II sebagai pelaku usaha, atau pemerintah sebagai regulator, atau badan usaha lain yang diberikan kewenangan untuk mengelola jasa-jasa tertentu di dalam industri kebandarudaraan.

\section{Putusan KPPU No. 13/KPPU-I/2014 tentang Penyediaan/Pelayanan Jasa Ground Handling Terkait Dengan Penerbangan Komersial Tidak Berjadwal (Irreguler Flight) di Bandar Udara I Gusti Ngurah Rai-Bali}

Putusan ini menitikberatkan pada persoalan bahwa PT Execujet Indonesia dan PT Angkasa Pura I (Persero) melakukan perjanjian praktik monopoli. Bentuk pelanggaran yang dilakukan PT Execujet Indonesia dan PT Angkasa Pura I (Persero) dalam pemberian layanan jasa ground handling di Bandar Udara I Gusti Ngurah Rai adalah melanggar Pasal 14 dan Pasal 17 Undang-Undang No. 5 Tahun 1999 tentang Larangan Praktek Monopoli dan Persaingan Usaha Tidak Sehat, yang terbukti karena adanya Perjanjian Kerja Sama Pengelolaan Pelayanan General Aviation Terminal yang ditandatangani oleh PT Execujet Indonesia dengan PT Angkasa Pura I (Persero).

Perjanjian Kerja Sama Pengelolaan Pelayanan GAT ditandatangani oleh PT Execujet Indonesia dengan PT Angkasa Pura I (Persero) pada 18 Juni 2013 di Bandara Internasional I Gusti Ngurah Rai-Bali. Mengacu Pasal 2 Perjanjian tersebut yang mengatur mengenai Ruang Lingkup Perjanjian, bahwa PT Execujet Indonesia diberikan hak eksklusif oleh PT Angkasa Pura I (Persero) untuk memberikan dan mengoperasikan layanan khusus di General Aviation Terminal untuk pesawat dan/atau penumpang, namun tidak terbatas pada beberapa hal.

Jika dilihat dari Perjanjian Kerjasama Usaha PT Execujet dengan PT Angkasa Pura I (persero) bukanlah seperti yang diamanatkan dan tertuang dalam Pasal 50 huruf a Undang-Undang Nomor 5 Tahun 1999, dalam pasal tersebut telah dijabarkan pengecualian untuk dapat melakukan monopoli. Dikarenakan perjanjian antara PT Execujet dengan PT Angkasa Pura I bukanlah sesuatu yang diamanatkan oleh peraturan perundang-undangan yang berlaku, mengakibatkan adanya praktik monopoli dan persaingan usaha tidak sehat terkait harga excessive atau berlebihan. Perbuatan melawan hukum adalah penetapan harga sepihak yang bertentangan dengan undang-undang dan/atau menghambat persaingan 
usaha adalah mengakibatkan pelaku usaha lain tidak dapat berkompetisi secara sehat. Bahwa Excessive Price (Harga yang berlebihan) dan penetapan harga sepihak telah bertentangan dengan undang-undang dan melanggar hukum.

\section{Putusan No. 08/KPPU- L/2016 tentang Praktek Monopoli yang dilakukan oleh PT Angkasa Pura Logistik di Terminal Kargo Bandar Udara Internasional Sultan Hasanuddin Makassar}

Putusan ini dalam intinya menitikberatkan pada pengelolaan atau pengoperasian Terminal Kargo Bandara Sultan Hasanuddin Makassar. PT Angkasa Pura I (Persero) melakukan kerjasama pengelolaan terminal kargo dengan menunjuk anak perusahaannya, yaitu PT Angkasa Pura Logistik sebagai operator terminal kargo sejak 1 Februari 2012. Kerjasama pengelolaan terminal kargo antara PT Angkasa Pura I (Persero) dengan PT Angkasa Pura Logistik dituangkan melalui Perjanjian Kerjasama Pengelolaan Terminal Kargo No. SP.6/HK.06.03/213/PD dan No. 02/APL-AP1/2013-DU tertanggal 18 Januari 2013. PT Angkasa Pura Logistik merupakan pelaku usaha tunggal yang mendapatkan hak eksklusif untuk melakukan jasa penyediaan fasilitas terminal untuk pelayanan angkutan kargo dan pos. PT Angkasa Pura Logistik juga merupakan satu-satunya Regulated Agent yang memberikan pelayanan jasa pemeriksaan dan pengendalian keamanan kargo dan pos di Terminal Kargo Bandar Udara Internasional Sultan Hasanuddin Makassar Sulawesi Selatan.

Adanya Perjanjian Kerjasama Pengelolaan Terminal Kargo No. SP.6/HK.06.03/213/PD dan No. 02/APLAP1/2013-DU antara PT Angkasa Pura I (Persero) dengan PT Angkasa Pura Logistik, yang di dalam perjanjian tersebut memuat ketentuan bahwa PT Angkasa Pura Logistik secara de facto maupun de jure telah memperoleh penunjukan langsung dari PT Angkasa Pura I (Persero) untuk mengelola terminal kargo Bandar Udara Sultan Hasanuddin Makassar. Oleh karena itu, perbuatan hukum ini telah melanggar Pasal 17 ayat (2) UU No. 5 Tahun 1999. Pemindahtanganan di atas telah melanggar Pasal 51 UU No. 5 Tahun 1999, karena hanya BUMN dan/atau badan atau lembaga yang dibentuk atau ditunjuk oleh Pemerintah saja yang dikecualikan dapat melakukan memonopoli, namun sebagaimana putusan di atas PT Angkasa Pura Logistik selaku anak perusahaan PT Angkasa Pura telah melakukan monopoli khususnya dalam hal menetapkan pengenaan tarif ganda (double charge) tanpa melakukan penyesuaian atas tarif yang berlaku sebelumnya. 
3. Putusan KPPU No. 03/KPPU-I/2017 tentang Dugaan Praktek Monopoli yang dilakukan oleh PT. Angkasa Pura II (Persero) dalam penyediaan fasilitas terminal untuk pelayanan kargo dan pos yang Dikirim (Outgoing) dan Diterima (Icoming) melalui Bandar Udara Kualanamu

Putusan ini pada intinya menitikberatkan bahwa PT Angkasa Pura II (Persero) secara sah dan meyakinkan melanggar Pasal 17 ayat (1) dan (2) UndangUndang No. 5 Tahun 1999. Terdapat perilaku praktik monopoli yang dilakukan PT Angkasa Pura II dalam bentuk penetapan tarif yang eksesif seperti penetapan Harga Pokok Produksi (HPP) dari tarif Jasa Kargo dan Pos Pesawat Udara (JKP2U). Selain itu juga dalam penetapan tarif pelayanan gudang di terminal kargo yang tinggi dan/atau tidak ada penyesuaian tarif penanganan kargo untuk kargo outgoing setelah penetapan Regulated Agent (RA) yaitu PT Apollo Kualanamoo serta penambahan kegiatan dan biaya dikawasan pergudangan yang memberikan nilai tambah dan merugikan konsumen. Hal tersebut mengakibatkan dampak kepada kepentingan umum berupa biaya logistik yang tinggi dan akan memengaruhi perekonomian nasional, disebabkan karena pengguna jasa yang menggunakan jasa PT Angkasa Pura II akan dibebankan tambahan biaya. Sehingga faktor adanya praktik monopoli dapat terbukti.

Kasus ini hampir sama dengan kasus sebelumnya hanya saja dalam putusan ini yang dijadikan sebagai terlapor adalah PT Angkasa Pura II (persero) karena wilayah Bandar udara dibawah kewenangan PT Angkasa Pura II (persero). Jika dilihat dalam putusan KPPU memang ada suatu kerjasama antara PT Angkasa Pura II (persero) dengan PT Appolo Kualanamo dengan adanya penetapan Regulated Agent tersebut. Karena setelah penetapan Regulated Agent tersebut terjadi kenaikan harga yang menguntungkan pihak PT Angkasa Pura II dengan Regulated Agent yang ditunjuk.

Keadaan yang terjadi dalam kasus ini bukanlah seperti yang diamanatkan Pasal 50 huruf a Undang-Undang Nomor 5 Tahun 1999, dalam pasal tersebut telah dijabarkan pengecualian untuk dapat melakukan monopoli karena hanya menguntungkan

beberapa pihak tanpa mempertimbangkan pihak lain dan peyedia jasa lain yang serupa. Selain itu penetapan Regulated Agent yang dikerjasamakan dalam penetapan harga tidak dituangkan atau tidak ditunjuk secara sah oleh peraturan perundang-undangan yang berlaku. Oleh karenanya, mengakibatkan adanya Praktek Monopoli dan Persaingan Usaha Tidak Sehat terkait harga excessive atau berlebihan.

Perbuatan melawan hukum yang terjadi adalah penetapan harga sepihak yang bertentangan dengan undang-undang dan/atau menghambat persaingan 
usaha sehingga mengakibatkan pelaku usaha lain tidak dapat berkompetisi secara sehat.

Penyelenggaraan monopoli dan/atau pemusatan kegiatan produksi dan/atau pemasaran barang dan/atau jasa oleh negara terhadap kegiatan yang berkaitan dengan produksi dan/atau pemasaran atas barang dan/atau jasa yang menguasai hajat hidup orang banyak serta cabang produksi yang penting bagi negara, diutamakan dan terutama diselenggarakan oleh BUMN. Namun dari 3 kasus di atas, PT Angkasa Pura I (Persero) dan PT Angkasa Pura II (Persero) selaku BUMN justru melakukan praktik monopoli dengan pemindahtanganan tugas dan kebijakan kepada badan usaha lain yang dalam ketentuan peraturan perundang-undangan izinnya tidak dapat dipindahtangankan. Sebagaimana diketahui mengenai izin pengelolaan bandar udara tertuang dalam Peraturan Menteri Perhubungan Nomor 56 Tahun 2015 tentang Kegiatan Pengusahaan di Bandar Udara jo Peraturan Menteri Perhubungan Nomor 187 Tahun 2015 tentang Perubahan Atas Peraturan Menteri Perhubungan Nomor PM 56 Tahun 2015 Tentang Kegiatan Pengusahaan Bandar Udara.

Selain pemindahtanganan tersebut seringkali PT Angkasa Pura I (Persero) dan PT Angkasa Pura II (Persero) memberikan hak-hak eksklusif kepada salah satu badan usaha yang telah melakukan perjanjian dengan PT Angkasa Pura I (Persero) dan PT Angkasa Pura II (Persero) dengan keuntungan hanya diperuntukkan kedua belah pihak yang bersepakat. PT Angkasa Pura I (Persero) dan PT Angkasa Pura II (Persero) justru melakukan penyalahgunaan kedudukan.

Praktik monopoli yang dilakukan oleh PT Angkasa Pura I (Persero) dan PT Angkasa Pura II (Persero) marak terjadi karena kurangnya pengawasan dan evaluasi dari Kementerian Perhubungan Republik Indonesia. Padahal dalam Peraturan Menteri Perhubungan Nomor 56 Tahun 2015 tentang Kegiatan Pengusahaan di Bandar Udara jo Peraturan Menteri Perhubungan Nomor 187 Tahun 2015 tentang Perubahan Atas Peraturan Menteri Perhubungan Nomor PM 56 Tahun 2015 tentang Kegiatan Pengusahaan Bandar Udara dalam Pasal 17 ayat (2) sudah mengamanatkan mengenai pelaporan untuk pengusahaan Bandar udara.

PT Angkasa Pura yang dikenal sebagai BUMN dalam ketiga putusan di atas tidak dapat melindungi dirinya dari jerat pelanggaran praktik monopoli dan persaingan usaha tidak sehat dengan Pasal 50 dan Pasal 51 Undang-Undang No. 5 Tahun 1999 tentang Larangan Praktek Monopoli dan Persaingan Usaha Tidak Sehat. Ketentuan tersebut tidak dapat melindungi praktik usaha-usaha perusahaan dibawah BUMN dari dugaan monopoli yang dilakukan. Meskipun 
terdapat pasal yang memperbolehkan monopoli atau persekongkolan, namun kaidah monopoli yang diperbolehkan oleh peraturan perundang-undangan harus sesuai dengan yang tertuang dalam peraturan perundang-undangan.

\section{Penyelenggaraan Kegiatan Usaha Kebandarudaraan yang Sesuai dengan Hukum Persaingan Usaha}

Kebijakan persaingan terdiri dari serangkaian langkah atau upaya yang dapat digunakan untuk mempromosikan perilaku pelaku usaha dan struktur pasar yang kompetitif, termasuk hukum persaingan yang komprehensif dan menjadi dasar dalam menindak perilaku anti persaingan. ${ }^{9}$ Persaingan usaha dapat dipahami seperti perilaku manusia dalam posisinya sebagai konsumen maupun produsen yang tengah berusaha memenuhi kebutuhan yang tidak terbatas dengan sumber daya yang terbatas. Bersaingnya para penyedia jasa maupun barang dalam mendapatkan mangsa pasar, keuntungan serta target penjualan.

Dengan adanya persaingan usaha tersebut maka diperlukan suatu hukum atau tata aturan perundang-undangan yang dimaksudkan untuk mengatur persaingan usaha. Pengaturan ini diperlukan agar kegiatan usaha selalu dalam kaidah yang adil bagi seluruh pihak, baik antar penjual atau penyedia jasa dan barang maupun konsumen. Hukum persaingan diciptakan dalam rangka mendukung terbentuknya sistem ekonomi pasar, agar persaingan antar pelaku usaha dapat tetap hidup dan berlangsung secara sehat, sehingga konsumen dapat terlindungi dari ajang eksploitasi bisnis. ${ }^{10}$

Undang-undang mengenai persaingan usaha di Indonesia pada saat ini berpatok pada Undang-Undang Nomor 5 Tahun 1999 tentang Larangan Praktek Monopoli dan Persaingan Tidak Sehat. Diundangkannya UU No. 5 Tahun 1999 ini, secara historis berawal dari belum tersedianya secara cukup suatu undangundang yang secara komprehensif dan memadahi untuk mengatur mengenai persaingan usaha di Indonesia. ${ }^{11}$ Undang-undang yang mengatur mengenai praktik monopoli dan persaingan usaha tidak sehat tersebut dapat menjadi patokan perilaku para pelaku usaha. Tujuan dari Undang-Undang Persaingan Usaha adalah untuk menciptakan efisiensi pada ekonomi pasar demi peningkatan

9 Daniel Agustino, "Faktor Penentu Dampak Aktivitas Anti Persaingan dan Pengecualian UU No. 5/1999 Pasal 50 huruf g”, Jurnal Persaingan Usaha, Edisi 1, 2009, hlm. 20.

10 Wafiya, "Politik Hukum Pembentukan Undang-Undangan Larangan Praktek Monopoli dan Persaingan Usaha Tidak Sehat”, Fiat Justisia Jurnal Ilmu Hukum, Volume 8 No. 4, Oktober-Desember 2014, hlm. 660

11 Rachmadi Usman, Hukum Persaingan Usaba di Indonesia, Cetakan Pertama, Jakarta: Sinar Grafika, 2013, hlm. 26 
kesejahteraan masyarakat, dengan mencegah monopoli, mengatur persaingan yang sehat dan bebas, serta memberikan sanksi terhadap para pelanggarnya. ${ }^{12}$

Undang-Undang No. 1 Tahun 2009 tentang Penerbangan telah mengatur bahwa peran serta swasta dan persaingan usaha serta perlindungan konsumen termasuk aspek penting dalam penyelenggaraan penerbangan nasional. Pernyataan itu diperjelas lagi dalam asas dan tujuan Undang-Undang No. 1 Tahun 2009 yang memasukkan prinsip/asas keterbukaan dan antimonopoli serta tujuan penyelenggaraan penerbangan yang menghindari praktik persaingan usaha yang tidak sehat. Dibandingkan dengan Undang-Undang Penerbangan yang lama yaitu Undang-Undang Nomor 15 Tahun 1992, sama sekali tidak mencantumkan asas persaingan usaha ataupun sedikit membahas mengenai persaingan usaha.

Ditambahkannya aspek antimonopoli atau prinsip pro-persaingan usaha di dalam ketentuan Undang-Undang Nomor 1 Tahun 2009 tentang Penerbangan merupakan indikasi bahwa pemerintah sesungguhnya telah membuka kesempatan bagi seluruh pihak yang mampu untuk bersaing secara sehat sesuai kaidah peraturan perundang-undangan dalam industri penerbangan, termasuk di dalamnya di sektor kebandarudaraan yang menjadi salah satu sektor usaha di Indonesia.

Peraturan mengenai tata kelola kegiatan usaha kebandarudaraan belum diiringi oleh peraturan yang tegas dan jelas. Pengelolaan jasa kebandarudaraan di Indonesia saat ini masih bersifat sentralistik yang berpusat kepada hak dikuasai negara. Sifat monopoli Bandar udara di Indonesia masih dikukuhkan dengan pendelegasian kewenangan yang diberikan oleh pemerintah kepada pelaku usaha tertentu. Pelaku usaha tersebut yaitu PT Angkasa Pura (persero) yang dibagi menjadi PT Angkasa Pura I (Persero) dan PT Angkasa Pura II (Persero) untuk dua wilayah kewenangan yang berbeda yang menjadi kepanjangan tangan dari pemerintah. PT Angkasa Pura untuk menjadi operator bandar udara sekaligus regulator yang berwenang mengeluarkan kebijakan dalam bentuk Surat Keputusan Direksi dan menentukan pelaku usaha mana yang dapat bekerjasama melakukan kegiatan usaha di bandar udara.

Perlu dibuat suatu peraturan pelaksana Undang-Undang No. 1 Tahun 2009 yang secara tegas dan jelas khusus mengatur sektor kebandarudaraan mengenai batasan delegasi kewenangan oleh pemerintah kepada PT Angkasa Pura I (Persero) dan PT Angkasa Pura II (Persero). Tidak berhenti pada regulasi yang

12 Susanti Adi Nugroho, Hukum Persaingan Usaha di Indonesia Dalam Teori dan Praktek Serta Penerapan Hukumnya, Cet. 1, Jakarta: Kencana Prenada Media Group, 2012, hlm. 5. 
jelas dan tegas, dari aspek bisnis/perdata, peraturan mengenai kebandarudaraan perlu memiliki sinergi dengan aspek hukum persaingan usaha sebagai upaya penegakkan (law enforcement) hukum persaingan usaha di sektor kebandarudaraan. Hal itu dapat dilakukan dengan harmonisasi peraturan perundang-undangan yang terkait dengan persaingan usaha dalam sektor kebandarudaraan dan sinkronisasi antara lembaga yang berwenang untuk membuat aturan dan melaksanakan aturan itu seperti Kementerian Perhubungan, PT Angkasa Pura I (Persero) dan PT Angkasa Pura II (Persero). Adanya pengaturan-pengaturan untuk menjaga agar dunia usaha bersaing secara sehat, jujur dan adil ini merupakan suatu syarat mutlak bagi suatu negara yang ingin maju menuju sistem ekonomi dan politik yang modern, sebab persaingan merupakan suatu elemen yang esensial dalam sistem perekonomian modern. ${ }^{13}$

Sebagai upaya pencegahan peraturan yang bertentangan dengan hukum persaingan usaha, pemerintah dapat mengacu pada OECD Toolkit Regulatory Impact Assessment yaitu pendekatan sistemik untuk menilai secara kritis efek positif dan negatif dari regulasi dan alternatif non-regulasi yang diusulkan dan yang sudah ada. OECD (Organisation For economic Coperation and Development) merupakan organisasi kerjasama dalam pembangunan ekonomi, namun saat ini Indonesia belum bergabung dengan organisasi ini. Toolkit tersebut memberikan kerangka kerja analisis yang diperlukan oleh para regulator dan pembuat undang-undang dalam rangka upaya mengurangi atau menghindari masalahmasalah dalam penegakkan regulasi mengenai persaingan usaha.

Berkaitan dengan permasalahan persaingan, pemerintah dapat mengacu pada OECD Competition Assessment Toolkit. Toolkit tersebut dapat membantu pemerintah untuk menghilangkan hambatan kompetisi dengan menyediakan metode untuk mengidentifikasi hambatan yang tidak perlu pada kegiatan pasar dan mengembangkan alternatif, langkah-langkah yang tidak terlalu membatasi yang masih mencapai tujuan kebijakan pemerintah. Hal itu dilakukan dengan membantu para pembentuk undang-undang dalam mengidentifikasi kemungkinan alternatif-alternatif yang dapat mengurangi atau menghilangkan kerugian potensial terhadap persaingan usaha sementara tetap melanjutkan usaha untuk mencapai tujuan-tujuan kebijakan yang diinginkan.

Zuhro Puspitasari dalam kajiannya mengusulkan perlunya rekonsepsi pengecualian praktik monopoli yang dilakukan oleh BUMN. Adapun rekonsepsi yang diusulkan tersebut ditujukan untuk lebih megefisiensikan penyelenggaraan usaha oleh BUMN namun tidak terjerat larangan monopoli.

13 Yoza Wirsan Armanda, “Analisa Terhadap Undang-Undang Persaingan Usaha dan Undang-Undang Perlindungan Konsumen”, Jurnal Persaingan Usaha, Edisi 1, Tahun 2009, hlm. 227 
Pertama, sinergi BUMN merupakan tindakan yang termasuk dalam monopoli BUMN yang dikecualikan dari ketentuan monopoli dalam UndangUndang Persaingan Usaha. Sebagaimana dijelaskan sebelumnya bahwa terjadi ketidaksinkronan antara KPPU dan Peraturan Menteri Negara BUMN Nomor 05/MBU/2008. Kedua, dipisahkannya penunjukan langsung melalui beauty contest dari pelanggaran persekongkolan tender. Ketiga, konsepsi monopoli BUMN perlu mengakomodir kerjasama yang dilakukan BUMN dengan pihak lain dan terlepas dari pelanggaran dalam Undang-Undang Persaingan Usaha. Keempat, monopoli atau pemusatan kegiatan yang diselenggarakan oleh BUMN tidak perlu dibatasi pada barang atau jasa yang menguasai hajat hidup orang banyak. ${ }^{14}$

Usulan rekonseptualisasi tersebut tentu juga bisa menjadi alternatif upaya penyesuaian pengecualian larangan monopoli. Hal ini agar kegiatan usaha yang dilakukan oleh BUMN tidak mesti selalu dinilai melanggar ketentuan larangan monopoli sementara di dalamnya telah dilakukan sesuai manajemen bisnis (ekonomi). Namun, keseimbangan antara aspek hukum dan ekonomi dalam penyelenggaraan usaha negara oleh BUMN ini perlu menjadi perhatian dalam penyesuaian hukum persaingan usaha ke depan. Sebab, hakikat dari hukum persaingan usaha adalah hukum yang mengatur setiap pelaku usaha untuk bebas bersaing dalam rangka melakukan kegiatan usaha untuk memperoleh keuntungan yang maksimal tanpa merugikan kompetitor lainnya. ${ }^{15}$

\section{Penutup}

Berdasarkan analisis di atas dapat disimpulkan; Pertama, secara umum, bentuk-bentuk pelanggaran Undang-Undang Nomor 5 Tahun 1999 tentang Larangan Praktek Monopoli dan Persaingan Usaha Tidak Sehat telah terbukti dilakukan oleh Badan Usaha Milik Negara (BUMN), yakni PT Angkasa Pura yang terbagi dalam dua wilayah kewenangan yang berbeda PT Angkasa Pura I (persero) dan PT Angkasa Pura II (persero) dalam kegiatan usaha kebandarudaraan. Pasal yang dilanggar oleh PT Angkasa Pura selaku BUMN antara lain Pasal 17 Undang-Undang No. 5 Tahun 1999 mengenai monopoli yang merupakan kegiatan yang dilarang oleh undang-undang. Pelanggaran sebagaimana terdapat dalam putusan di atas terjadi karena inkonsistensi perilaku pelaku usaha dalam menjalankan kontrak kegiatan usaha kebandarudaraan

14 Zuhro Puspitasari, "Rekonsepsi Pengecualian Monopoli Yang Diselenggarakan Oleh Badan Usaha Milik Negara Dalam Hukum Persaingan Usaha di Indonesia", Jurnal Panorama Hukum, Vol. 2, No. 2, 2017, hlm. 240

15 I Made Sarjana, "Analisis Pendekatan Ekonomi dalam Hukum Persaingan Usaha”, Jurnal Trunojoyo, Vol. 8, No. 2, 2013, hlm. 19 
sehingga terjadi praktik monopoli yang dilakukan PT Angkasa Pura I dan II, yang jelas-jelas sudah bertentangan dengan Pasal 50 huruf a dan Pasal 51 UndangUndang No. 5 Tahun 1999 tentang perbuatan yang dikecualikan dan bentuk monopoli yang diperbolehkan. Selain itu juga lantaran masih kurangnya pengawasan dan evaluasi dari Kementerian Perhubungan Republik Indonesia.

Kedua, Undang-Undang No. 1 Tahun 2009 tentang Penerbangan sebenarnya telah memuat prinsip antimonopoli dan pro-persaingan. Namun pada praktiknya sektor kebandarudaraan di Indonesia masih menjadi domain pemerintah dalam pengelolaannya melalui BUMN khususnya. Sebagai upaya pencegahan peraturan yang bertentangan dengan hukum persaingan usaha, pemerintah dapat mengacu pada OECD Toolkit Regulatory Impact Assessment yaitu pendekatan sistemik untuk menilai secara kritis efek positif dan negatif dari regulasi dan alternatif nonregulasi yang diusulkan dan yang sudah ada. Selain langkah-langkah di atas juga sangat diperlukan perbaikan dalam hal regulasi tata kelola usaha kebandarudaraan yang masih bernuansa sentralistik monopolistik. Indonesia dapat menggabungkan trend yang telah dan sedang berlangsung di sebagian besar negara di dunia yaitu privatisasi bandara baik dalam bentuk kepemilikan saham sampai hak pengelolaan bandar udara. Swasta berhak menyelenggarakan kegiatan usaha kebandarudaraan dengan prinsip demokrasi ekonomi sesuai dengan prinsip hukum persaingan usaha Indonesia. Selanjutnya dengan menegakkan peraturan perundang-undangan yanga ada mengenai pengelolaan sektor-sektor kebandarudaraan, serta pengawasan yang lebih diperketat lagi kepada pelaku usaha pada sektor bandar udara. Dengan kata lain, perlu disusun suatu peraturan pelaksana mengenai pengelolaan sektor kebandarudaraan serta perlu diadakannya pembaharuan mengenai Peraturan Pemerintah yang mengadaptasi nilai-nilai dari UU No. 1 Tahun 2009 tentang Penerbangan sebagai peraturan pelaksana dibawah perundang-undangan.

\section{Daftar Pustaka}

\section{Buku}

Juwana, Hikmahanto, Bunga Rampai Hukum Ekonomi dan Hukum Internasional, Penerbit Lentera Hati, Tanpa Kota, 2001.

Sartono, Wardani, et,al., Bandar Udara Pengenalan dan Perancangan Geometrik Runway, Taxiway dan Apron, Gadjah Mada University Press, Yogyakarta, 2016.

Soekanto, Soerjono dan Sri Mamudji, Penelitian Hukum Normatif, Rajawali Press, Jakarta, 1995.

Usman, Rachmadi, Hukum Persaingan Usaha di Indonesia, Cetakan Pertama, Sinar Grafika, Jakarta, 2013. 
Wiradipradja, Saefullah, Pengantar Hukum Udara dan Ruang Angkasa, Buku I Hukum Udara, PT Alumni, Bandung, 2014.

\section{Jurnal}

Daniel Agustino, "Faktor Penentu Dampak Aktivitas Anti Persaingan dan Pengecualian UU No. 5/1999 Pasal 50 huruf g", Jurnal Persaingan Usaha, Edisi 1, 2009.

I Made Sarjana, “Analisis Pendekatan Ekonomi dalam Hukum Persaingan Usaha", Jurnal Trunojoyo, Vol. 8, No. 2, 2013.

Wafiya, "Politik Hukum Pembentukan Undang-Undangan Larangan Praktek Monopoli dan Persaingan Usaha Tidak Sehat", Fiat Justisia Jurnal Ilmu Hukum, Volume 8 No. 4, Oktober-Desember 2014.

Yoza Wirsan Armanda, "Analisa Terhadap Undang-Undang Persaingan Usaha dan Undang-Undang Perlindungan Konsumen", Jurnal Persaingan Usaha, Edisi 1, Tahun 2009.

Zuhro Puspitasari, "Rekonsepsi Pengecualian Monopoli Yang Diselenggarakan Oleh Badan Usaha Milik Negara Dalam Hukum Persaingan Usaha di Indonesia", Jurnal Panorama Hukum, Vol. 2, No. 2, 2017.

\section{Peraturan-Perundang Undangan}

Undang-Undang Dasar Negara Republik Indonesia Tahun 1945

Undang-Undang Nomor 5 Tahun 1999 tentang Larangan Praktek Monopoli dan Persaingan Tidak Sehat

Undang-Undang No. 1 Tahun 2009 tentang Penerbangan

Peraturan Menteri Perhubungan Nomor 56 Tahun 2015 tentang Kegiatan Pengusahaan di Bandar Udara jo Peraturan Menteri Perhubungan Nomor 187 Tahun 2015 tentang Perubahan Atas Peraturan Menteri Perhubungan Nomor PM 56 Tahun 2015 Tentang Kegiatan Pengusahaan Bandar Udara

\section{Internet}

"Kargo Bandara", https://bandara.id/kargo/seputar-kargo-bandara diakses pada tanggal 01 Maret 2019 pukul 11:10 WIB

"Kebandarudaraan adalah segala sesuatu yang berkaitan dengan penyelenggaraan Bandar udara dan kegiatan lainnya dalam melaksanakan fungsi keselamatan, keamanan, kelancaran, dan ketertiban arus lalu lintas pesawat udara, penumpang, kargo dan/atau pos, tempat perpindahan intra dan/atau antarmoda serta meningkatkan pertumbuhan ekonomi nasional dan daerah", http://hubud.dephub.go.id/?id/page/detail/44 diakses pada tanggal 26 Maret 2019, pukul 12:04 WIB)

"Sejarah bandar udara", https://www.angkasapura2.co.id/id/tentang/sejarah diakses pada tanggal 22 Maret 2019 